\title{
DIGESTIBILITY OF FAT IN BROILER CHICKENS INFLUENCED BY DIETARY ADDITION OF SPICE HERBS
}

\author{
Nikola Puvača ${ }^{1}$, Dragana Ljubojević ${ }^{2}$, Dragomir Lukač ${ }^{1}$, Ljiljana Kostadinović ${ }^{3}$, Vidica Stanaćev ${ }^{1}$, \\ Sanja Popović ${ }^{3}$, Milica Živkov Baloš ${ }^{2}$, Nedeljka Nikolova ${ }^{4}$ \\ ${ }^{1}$ Faculty of Agriculture, University of Novi Sad, Trg Dositeja Obradovića 8, 21000 Novi Sad, Serbia \\ ${ }^{2}$ Scientific Institute of Veterinary Medicine "Novi Sad", Rumenački put 20, 21000 Novi Sad, Serbia \\ ${ }^{3}$ Institute of Food Technology, University of Novi Sad, Bulevar cara Lazara 1, 21000 Novi Sad, Serbia \\ 4 "Ss. Cyril and Methodius" University in Skopje, Institute of Animal Science, \\ Blvd. Ilinden 92a, 1000 Skopje, Republic of Macedonia \\ nikola.puvaca@stocarstvo.edu.rs
}

\begin{abstract}
This experiment was conducted to investigate the effects of garlic (Allium sativum L.), black pepper (Piper nigrum L.) and hot red pepper (Capsicum annuum L.) in broiler chicken nutrition on productive performances and crude fat digestibility. For biological research eight treatments with 1200 broiler chickens of hybrid line Hubbard in total were formed, in four replicates. Control treatment (T1) was fed with standard commercial mixtures based on corn meal and soybean meal. Experimental groups were fed with same commercial mixtures with addition of spice herbs as follows: garlic 0.5 (T2) and $1.0 \mathrm{~g} / 100 \mathrm{~g}$ (T3), black pepper 0.5 (T4) and $1.0 \mathrm{~g} / 100 \mathrm{~g}$ (T5), hot red pepper 0.5 (T6) and $1.0 \mathrm{~g} / 100 \mathrm{~g}$ (T7) and mixture of garlic, black pepper and hot red pepper (1:1:1) in total of $0.5 \mathrm{~g} / 100 \mathrm{~g}$ (T8). During the preparation period (first two weeks) chickens were fed with starter mixtures diets without addition of spice herbs. After this period, starter and grower diets were prepared according the plan till the end of experiment (42 days). At the end of experiment and on the basis of gained results it can be concluded that the chickens at experimental treatments T6 and T7 achieved statistically significant $(\mathrm{p}<0.05)$ higher final body masses $(2460.6$ and 2442.4 g) compared to the chickens at control and other treatments. When it comes to a highest digestibility of crude fat, treatments T2, T4 and T6 $(4.5 \mathrm{~g} / 100 \mathrm{~g})$ recorded statistically significant $(\mathrm{p}<0.05)$ differences compared to control treatment, but without significant differences $(\mathrm{p}>0.05)$ between experimental treatments. In this experiment addition of garlic, black pepper and hot red pepper had significant influence on fat digestibility and utilization as well as better production results compared to a control treatment.
\end{abstract}

Key words: garlic; black pepper; hot red pepper; nutrition; chickens; fat digestibility

\section{СВАРЛИВОСТ НА МАСТИТЕ ВО ИСХРАНАТА НА БРОЈЛЕРСКИ ПИЛИЫА СО ДОДАВАЊЕ ЗАЧИНСКИ БИЛКИ ВО ОБРОЦИТЕ}

Овој експеримент беше направен со цел да се испита влијанието на лукот (Allium sativum L.), црниот пипер (Piper nigrum L.) и лутата црвена пиперка (Capsicum anпиuт L.) во исхраната на бројлерски пилиња врз производните карактеристики и сварливоста на суровите масти. За истражувањето беа направени вкупно осум третмани на 1200 бројлерски пилиња од хибридната линија Hubbard, со по четири повторувања. Контролната група (Т1) беше хранета со комерцијални смеси со стандарден состав врз база на пченкарно брашно и соја. Експерименталните групи беа хранети со исти комерцијални смеси, но со додавање зачински билки како што следува: лук 0,5 (T2) и $1,0 \mathrm{~g} / 100 \mathrm{~g}$ (Т3), црн пипер 0,5 (Т4) и 1,0 g/100 g (T5), лута црвена пиперка 0,5 (T6) и $1,0 \mathrm{~g} / 100 \mathrm{~g}(\mathrm{~T} 7)$ и смеса на лук, црн пипер и лута црвена пиперка (1:1:1) во вкупно $0,5 \mathrm{~g} / 100 \mathrm{~g}$ (T8). Првите две недели бројлерите беа на подготвителен период со стартер-смеси без додавање на зачинските билки, потоа пилињата се хранеа со гровер и финишер-смеси според планот за исхрана до крајот на експериментот, кој траеше 42 дена. На крајот од експериментот и врз основа на постигнатите резултати можеше да се заклучи дека бројлерските пилиња од експерименталните групи Т6 и Т7 постигнале статистички значајно (p < $0,05)$ повисока крајна телесна маса $(2460,6$ и $2442,4 \mathrm{~g})$ во споредба со пилињата од контролната и другите групи. Кога станува збор за највисока сварливост на суровите масти, третманите Т2, Т4 и Т6 (4,5 g/100 g) постигнале статистички значајни $(\mathrm{p}<0,05)$ разлики во споредба со контролната група, но немало сигнификантни 
разлики $(\mathrm{p}>0,05)$ помеѓу експерименталните групи. Во овој експеримент додавањето на лукот, црниот пипер и лутата црвена пиперка имаше значајно влијание врз сварливоста и искористливоста на суровите масти, како и подобри производни резултати во споредба со контролната група.

Клучни зборови: лук; црн пипер; лута црвена пиперка; исхрана; пилиња; сварливост на масти

\section{INTRODUCTION}

Besides of important role of spices, medicinal herbs and aromatic plants in daily human nutrition these additives have been usefully used in animal nutrition for improvement of health, utilization of nutrients and animal wellbeing. Removal of antibiotics as growth promoters has led to animal performance problems, feed conversion ratio increase, and a rise in the incidence of certain animal diseases [30]. The alternatives to antibiotics as growth promoters are numerous $[22,12,25,19]$. Plant derived additives used in animal nutrition to improve performance have been called "phytogenic feed additives" [31]. The primary mode of action of these growth promoting feed additives can be attributed mainly to the stabilization of feed hygiene and also from the beneficial effect on the gastrointestinal microbiota through controlling pathogens [21]. Spices have been recognized for long time regarding their digestive stimulant action. Several spices are also employed in medicinal preparations against digestive disorders in traditional and Indian medicine. Earlier reports on the digestive stimulant action of spices are largely empirical; only in recent years, this beneficial attribute of spices has been authenticated in exhaustive animal studies. Animal studies have shown that many spices induce higher secretion of bile acids which play a vital role in fat digestion and absorption. When consumed through the diet, spices produce significant stimulation of the activities of pancreatic lipase, amylase and proteases. A few of them also have been shown beneficial effect on the terminal digestive enzymes of small intestinal mucosa. Concomitant with such a stimulation of either bile secretion or activity of digestive enzymes by spices, leads to an accelerated digestion and reduction in the feed transit time in the gastrointestinal tract [17]. In commercial broiler production mainly powder forms or essential oils of oregano (Origanum vulgare), rosemary (Rosmarinus officinalis), sage (Salvia officinalis), thyme (Thymus vulgaris), garlic (Allium sativum), black pepper (Piper nigrum) and chilli (Capsicum annuum) are used singly or in combination as feed additives [8, 19, 18]. Garlic (Allium sativum L.), is a well known spice and herbal medicine for the preven- tion and treatment of a variety of diseases [2]. It has been shown to exhibit antimicrobial, antioxidant, and anti-hypertensive properties [23]. As a natural feed additive, garlic has been reported to improve broiler growth, feed conversion ratio and decreased mortality [28]. The mechanism of action of garlic as a growth promoter is yet to be fully elucidated. It was considered that garlic might have the ability to improve absorptive capacity of the small intestine via structural alterations [16]. In broilers, it was reported that garlic, as a natural feed additive have improved broiler growth and feed conversion ratio, and decreased mortality rate [26]. Furthermore, this additive has a relatively low market price and if it is added in small amounts of 0.2 to $2 \%$, do not increase production costs, which is of particular importance to manufacturers [32]. Black pepper is known as spices due to its pungent quality. Black pepper is found to improve feed digestibility [15]. Black pepper was found to be rich in glutathione peroxidase and glucose-6-phosphate dehydrogenase, and it has been shown that piperine can dramatically increase absorption of selenium, vitamin B complex and $\beta$ carotene as well as other nutrients [11, 27]. Piperine enhances the thermogenesis of lipids and accelerates energy metabolism in the body and also increases the serotonin and $\beta$-endorphin production in the brain [4]. Piperine is an active alkaloid that modulates benzopyrene metabolism through cytochrome P450 enzyme, which is important for the metabolism and transport of xenobiotic and metabolites [20]. Investigation of Abou-Elkhair et al. [1] showed that black pepper in broiler nutrition had influenced on improved health status trough serum globulin concentration increase. Hot red pepper plays an important role in decreasing the deposition of cholesterol and fat in the body and contributes to decrease levels of triglycerides and work to support the vascular system in the body. Pepper efficiency compounds are consisting of capsaicin, capsisin and capsantine that some of them allay rheumatic aches. A recent studies involved in poultry performance showed that blends of active compounds for hot red pepper causes chemopreventive and chemotherapeutic effects.

Aim of this study was to investigate the effects of garlic (Allium sativum L.), black pepper 
(Piper nigrum L.) and hot red pepper (Capsicum annuum L.) in broiler chicken nutrition on productive performances and crude fat digestibility.

\section{MATERIAL AND METHODS}

\section{Animal nutrition, housing and sample collection}

Biological experiment were carried out under production conditions at the experimental farm "Pustara" in property of the Faculty of Agriculture, Department of Animal Science in Novi Sad. At the beginning of experiment, eight treatments of 150 one day old broiler chickens of hybrid line Hubbard per treatment in four replication on a total of 1200 chickens were formed. For chicken feeding three mixtures were used, starter, grower and finisher (Table 2). The first 14 days, during the preparatory period, chicks were fed with starter mixture. Following the preparation period, chicks were fed the next 21 days with grower mixtures, and then the last 7 days of fattening period with finisher mixtures according the experimental desing given in Table 1. During the 42 days experiment, chicks were fed and watered ad libitum, and microclimate conditions were regularly monitored. Chickens were on the floor holding system. Control of body weight and feed consumption was performed on the weekly basis. Collection of feces samples was carried out for three days at the end of IV, V and VI week of fattening period. Samples of grower and finisher feed mixtrure, as well as feces samples was analyzed with standard AOCS method for crude fat determination.

\section{Digestibility of crude fat (CFD)}

The digestibility of crude fat (CFD) was calculated for the grower and finisher feeding period according to the equation [14]:

$$
\begin{aligned}
\mathrm{CFD}= & \text { crude fat in diet mixture }-(\text { crude fat in } \\
& \text { feces } / \text { crude fat in diet mixture })
\end{aligned}
$$

\section{Statistical analyses}

Statistical analyses were conducted using the Statistica for Windows statistical package program, (version 12) to determine if variables differed between groups. Significant effects were further explored using analysis of variance (ANOVA), LSM and Fisher's LSD post-hoc multiple range test to ascertain differences among treatment means. A level of significance was set at $p<0.05$.
Table 1

\begin{tabular}{|c|c|c|c|c|}
\hline \multirow{3}{*}{$\begin{array}{l}\text { Experimental } \\
\text { treatmens }\end{array}$} & \multicolumn{4}{|c|}{$\begin{array}{l}\text { Concetration of additives in chicken diets } \\
\qquad \mathrm{g} / 100 \mathrm{~g}\end{array}$} \\
\hline & \multirow{2}{*}{ Additive } & $\begin{array}{l}\text { In } \\
\text { starter }\end{array}$ & $\begin{array}{l}\text { In } \\
\text { grower }\end{array}$ & $\begin{array}{l}\text { In } \\
\text { finisher }\end{array}$ \\
\hline & & $\begin{array}{l}1-14 \\
\text { days }\end{array}$ & $\begin{array}{l}15-35 \\
\text { days }\end{array}$ & $\begin{array}{c}36-42 \\
\text { days }\end{array}$ \\
\hline $\mathrm{T} 1$ & Control treatment & 0.0 & 0.0 & 0.0 \\
\hline $\mathrm{T} 2$ & Garlic powder & 0.0 & 0.5 & 0.5 \\
\hline $\mathrm{T} 3$ & Garlic powder & 0.0 & 1.0 & 1.0 \\
\hline $\mathrm{T} 4$ & Black pepper powder & 0.0 & 0.5 & 0.5 \\
\hline T5 & Black pepper powder & 0.0 & 1.0 & 1.0 \\
\hline T6 & Hot red pepper powder & 0.0 & 0.5 & 0.5 \\
\hline $\mathrm{T} 7$ & Hot red pepper powder & 0.0 & 1.0 & 1.0 \\
\hline $\mathrm{T} 8$ & $\begin{array}{l}\text { Mixture of garlic, } \\
\text { black pepper and hot } \\
\text { red pepper }(1: 1: 1)\end{array}$ & 0.0 & 0.5 & 0.5 \\
\hline
\end{tabular}

Experimental design with chickens

Table 2

Chemical composition of dietary mixtures, $\mathrm{g} / 100 \mathrm{~g}$

\begin{tabular}{lccc}
\hline \hline \multirow{2}{*}{ Nutrients } & \multicolumn{3}{c}{ Diet mixtures } \\
\cline { 2 - 4 } & Starter & Grower & Finisher \\
\hline Dry matter & 89.4 & 89.3 & 89.4 \\
Moisture & 10.5 & 10.7 & 10.5 \\
Crude protein & 21.1 & 20.7 & 17.3 \\
Crude fat & 3.9 & 3.9 & 4.7 \\
Crude fiber & 3.5 & 3.5 & 3.6 \\
Ash & 5.0 & 4.8 & 5.6 \\
Ca & 0.8 & 0.9 & 1.1 \\
P & 0.6 & 0.6 & 0.5 \\
Metabolic energy, $\mathrm{MJ} / \mathrm{kg}$ & 12.5 & 12.8 & 13.3 \\
\hline \hline
\end{tabular}

\section{RESULTS AND DISCUSSION}

Based on the obtained results it can be concluded that the addition of garlic, black pepper and hot red pepper in the diet of broiler chickens led to a statistically significant $(\mathrm{p}>0.05)$ differences in body weight (Table 3 ). At the end of the preparatory period chickens had uniform body weight with no statistical significant differences $(\mathrm{p}>0.05)$.

At the end of the third week, chickens in treatment T2 achieved highest body weight ( 818.5 
g) with statistically significant differences compared to the treatments T1, T4 - T8. Almost the same tendency was observed at the end of fourth week where the highest body masses were recorded in chickens at treatments with addition of 0.5 (T2) and $1.0 \mathrm{~g} / 100 \mathrm{~g} \mathrm{(T3)} \mathrm{of} \mathrm{garlic} \mathrm{powder}$ $(1202.3$ and $1204.9 \mathrm{~g})$ with statistically significant differences compared with $\mathrm{T} 1, \mathrm{~T} 4$ and $\mathrm{T} 5$, while the significant differences with treatments T6, T7 and T8 was absent. At the end of second fattening period, addition of hot red pepper in treatments T6 and T7 showed stimulating effect and led to statistically significant differences $(p<0.05)$ in body weight in relation to control and other experimental treatments. After the completion of experimental period the highest body weight of chicken was at treatment T6 $(2460.6 \mathrm{~g})$ which was followed by treatment T7 (2442.4 g) with statistically significant differences $(\mathrm{p}<0.05)$ compared to other treatments. Treatments with addition of garlic powder (T2, T3) achieved final body masses of 2371.1 and $2336.1 \mathrm{~g}$ which was statistically significant $(\mathrm{p}<0.05)$ higher than masses of chickens at treatments T1 (2075.8 g), T4 (2076.5 g) and T5 (2077.5 g). Addition of black pepper in treatments
T4 and T5 led to a statistically significant ( $\mathrm{p}<$ 0.05 ) lower body weight compared to other experimental treatments, but without significant differences $(p>0.05)$ compared to a control treatment T1. Lewis et al. [13] showed that addition of plant extracts to broiler chickens nutrition has some effects on performance but none of them were significant. These study have showed that the addition of medicinal herbs to the chickens diet have positive effect on production results what is in agreement with previous findings of Ashayerizadeh et al. [5]; Fadlalla et al. [7]; Stanaćev et al. [26]; AlKassie et al. [4]; Issa and Abo Omar [10]; Valiollahi et al. [29] and Puvača et al. [18]. Al-Harthi [3] found that broiler chicks fed diets supplemented with hot red pepper showed improved feed conversion ratio and concluded that the effect may be due to its simulative, carminative, digestive and antimicrobial properties, what is in consistent with our results. Hosseini [9] showed that black pepper increases digestion through prompt digestive liquids of stomach and eradicates infectious bacteria. Black pepper affects the absorption power, decreases material transit velocity and increases digestive enzymes.

Table 3

Body weight of chickens in experiment, $g$

\begin{tabular}{|c|c|c|c|c|c|c|c|c|}
\hline \multicolumn{2}{|c|}{$\begin{array}{c}\text { Experimental } \\
\text { treatments }\end{array}$} & \multirow{2}{*}{$\frac{1 \text { day }}{42.8^{\mathrm{a}}}$} & \multirow{2}{*}{$\frac{7 \text { days }}{162.7^{\text {a }}}$} & \multirow{2}{*}{$\frac{14 \text { days }}{388.6^{\mathrm{a}}}$} & \multirow{2}{*}{$\begin{array}{c}\text { Age of chickens } \\
21 \text { days }\end{array}$} & \multirow{2}{*}{$\frac{28 \text { days }}{1162.4^{\mathrm{b}}}$} & \multirow{2}{*}{$\frac{35 \text { days }}{1643.8^{\mathrm{c}}}$} & \multirow{2}{*}{$\frac{42 \text { days }}{2075.8^{\mathrm{d}}}$} \\
\hline $\mathrm{T} 1$ & LSM & & & & & & & \\
\hline 1 & $\mathrm{SE}_{\mathrm{LSM}}$ & 0.47 & 1.52 & 3.64 & 8.38 & 11.84 & 12.2 & 24.23 \\
\hline \multirow{2}{*}{$\mathrm{T} 2$} & LSM & $42.1^{\mathrm{a}}$ & $160.2^{\mathrm{a}}$ & $389.7^{\mathrm{a}}$ & $818.5^{\mathrm{a}}$ & $1202.3^{\mathrm{a}}$ & $1743.1^{b}$ & $2371.1^{b}$ \\
\hline & $\mathrm{SE}_{\mathrm{LSM}}$ & 0.47 & 1.63 & 3.84 & 8.41 & 11.8 & 12.16 & 23.96 \\
\hline \multirow{2}{*}{$\mathrm{T} 3$} & LSM & $42.2^{\mathrm{a}}$ & $159.7^{\mathrm{a}}$ & $386.4^{\mathrm{a}}$ & $804.6^{\mathrm{ab}}$ & $1204.9^{\mathrm{a}}$ & $1737.2^{b}$ & $2336.1^{b c}$ \\
\hline & $\mathrm{SE}_{\mathrm{LSM}}$ & 0.47 & 1.64 & 3.79 & 8.5 & 11.75 & 11.94 & 23.43 \\
\hline \multirow{2}{*}{$\mathrm{T} 4$} & LSM & $42.4^{\mathrm{a}}$ & $159^{\mathrm{a}}$ & $384.2^{\mathrm{a}}$ & $754.1^{\mathrm{d}}$ & $1117.1^{\mathrm{c}}$ & $1577.8^{\mathrm{d}}$ & $2076.5^{\mathrm{d}}$ \\
\hline & $\mathrm{SE}_{\mathrm{LSM}}$ & 0.47 & 1.62 & 3.79 & 8.41 & 11.8 & 12.39 & 24.42 \\
\hline \multirow{2}{*}{ T5 } & LSM & $42.4^{\mathrm{a}}$ & $160.4^{\mathrm{a}}$ & $386.6^{\mathrm{a}}$ & $727.5^{\mathrm{e}}$ & $1055.6^{\mathrm{d}}$ & $1503.7^{\mathrm{e}}$ & $2077.8^{\mathrm{d}}$ \\
\hline & $\mathrm{SE}_{\mathrm{LSM}}$ & 0.47 & 1.62 & 3.86 & 8.35 & 11.75 & 12.16 & 23.96 \\
\hline \multirow{2}{*}{ T6 } & LSM & $42.5^{\mathrm{a}}$ & $162.5^{\mathrm{a}}$ & $385.3^{\mathrm{a}}$ & $770.5^{\text {cd }}$ & $1193.6^{\mathrm{ab}}$ & $1815.1^{\mathrm{a}}$ & $2460.6^{\mathrm{a}}$ \\
\hline & $\mathrm{SE}_{\mathrm{LSM}}$ & 0.47 & 1.63 & 3.86 & 8.29 & 11.84 & 12.25 & 24.05 \\
\hline \multirow{2}{*}{$\mathrm{T} 7$} & LSM & $42^{\mathrm{a}}$ & $161.6^{\mathrm{a}}$ & $385.1^{\mathrm{a}}$ & $762.4^{\mathrm{cd}}$ & $1183.6^{\mathrm{ab}}$ & $1812.1^{\mathrm{a}}$ & $2442.4^{\mathrm{a}}$ \\
\hline & $\mathrm{SE}_{\mathrm{LSM}}$ & 0.47 & 1.6 & 3.87 & 8.38 & 11.84 & 12.2 & 24.33 \\
\hline \multirow{2}{*}{$\mathrm{T} 8$} & LSM & $41.8^{\mathrm{a}}$ & $163.2^{\mathrm{a}}$ & $384.9^{\mathrm{a}}$ & $778.6^{\mathrm{c}}$ & $1178.7^{\mathrm{ab}}$ & $1717.5^{b}$ & $2297.8^{c}$ \\
\hline & $\mathrm{SE}_{\mathrm{LSM}}$ & 0.47 & 1.6 & 3.81 & 8.38 & 11.71 & 12.02 & 23.78 \\
\hline
\end{tabular}

Treatments with different letter indexes in the same column are statistically significantly different $(\mathrm{p}<0.05) \backslash$

${ }^{\mathrm{a}}$ - statistically no significant differences; ${ }^{\text {ab, bc, cd }}$ - statistically significant diferences 
Results in Table 4 show the digestibility of crude fat in broiler chickens. Amount of crude fat in the diet mixtures, both grower and finisher between the treatments was uniform, without statistically significant differences $(p>0.05)$. From the results of crude fat amount in feces significant differences $(p<0.05)$ could be observed. The highest amount of crude fat in feces $(3.5 \mathrm{~g} / 100 \mathrm{~g})$ at the end of IV week was recorded in chickens at treatment T1 which was statistically significant $(\mathrm{p}<$ $0.05)$ compared with all other experimental treatments. The smallest amount of crude fat in feces $(2.2 \mathrm{~g} / 100 \mathrm{~g})$ was recorded in chickens on treatment T3 with statistically significant differences compared with control and experimental treatments. The same tendency was observed at the end of VI week, only with the smallest amount of crude fat $(1.8 \mathrm{~g} / 100 \mathrm{~g})$ in the feces of chickens in treatment T6 with significant differences $(p<0.05)$. When it comes to a highest digestibility of crude fat, treatments $\mathrm{T} 2, \mathrm{~T} 4$ and $\mathrm{T} 6(4.5 \mathrm{~g} / 100 \mathrm{~g})$ recorded statistically significant $(p<0.05)$ differences compared to control treatment, but without significant differences $(p>0.05)$ between experimental treatments. In this experiment addition of garlic, black pepper and hot red pepper had significant influence on crude fat digestibility and utilization. These effects of spice herbs can be attributed to their stimulation of gastric functions and intensify of salivary flow and gastric juice secretion, which help in digestion [17]. It has been found that black pepper enhances digestive tract function. In experiments with rats and mice it was reported that black pepper and piperine can stimulate digestive enzymes, modify stomach secretions, alter gastrointestinal food transit time, and inhibit diarrhoea [6, 24]. Abou-Elkhair et al. [1] in their experiment with addition of $0.5 \%$ of black pepper in broiler chicken nutrition found that the pepper dietary addition led to an improved feed conversion ratio through the entire fattening period. In our study as well as in a study of Al-Kassie et al. [4], addition of hot red pepper in broiler chicken nutrition led to a better feed utilization. The digestive stimulant action of these spices herbs seems to be mediated by liver stimulations to secrete bile rich in bile acids, components that are vital for fat digestion and absorption, and by a stimulation of enzyme activities that are responsible for digestion [17].

Table 4

Digestibility of crude fat, $\mathrm{g} / 100 \mathrm{~g}$

\begin{tabular}{|c|c|c|c|c|c|c|c|c|c|c|}
\hline \multirow{2}{*}{\multicolumn{2}{|c|}{$\begin{array}{c}\text { Nutrients } \\
\text { Week }\end{array}$}} & \multicolumn{3}{|c|}{ Crude fat in diet } & \multicolumn{3}{|c|}{ Crude fat in feces } & \multicolumn{3}{|c|}{ Digested crude fat } \\
\hline & & IV & $\mathrm{V}$ & VI & IV & $\mathrm{V}$ & VI & IV & $\mathrm{V}$ & VI \\
\hline \multirow{2}{*}{$\mathrm{T} 1$} & LSM & $3.8^{\mathrm{a}}$ & $3.8^{\mathrm{a}}$ & $4.9^{\mathrm{a}}$ & $3.5^{\mathrm{a}}$ & $3.3^{\mathrm{a}}$ & $3.3^{\mathrm{a}}$ & $3,0^{\mathrm{a}}$ & $3,0^{\mathrm{a}}$ & $4,2^{\mathrm{b}}$ \\
\hline & $\mathrm{SE}_{\mathrm{LSM}}$ & 0.11 & 0.11 & 0.04 & 0.05 & 0.02 & 0.01 & 0,12 & 0,12 & 0,04 \\
\hline \multirow{2}{*}{$\mathrm{T} 2$} & LSM & $3.8^{\mathrm{a}}$ & $3.8^{\mathrm{a}}$ & $4.9^{\mathrm{a}}$ & $2.4^{\mathrm{d}}$ & $2.7^{\mathrm{b}}$ & $2.1^{\mathrm{f}}$ & $3,1^{\mathrm{a}}$ & $3,1^{\mathrm{a}}$ & $4,5^{\mathrm{a}}$ \\
\hline & $\mathrm{SE}_{\mathrm{LSM}}$ & 0.11 & 0.11 & 0.04 & 0.05 & 0.02 & 0.01 & 0,12 & 0,12 & 0,04 \\
\hline \multirow{2}{*}{$\mathrm{T} 3$} & LSM & $3.8^{\mathrm{a}}$ & $3.8^{\mathrm{a}}$ & $4.9^{\mathrm{a}}$ & $2.2^{\mathrm{e}}$ & $2.3^{\mathrm{d}}$ & $2.5^{\mathrm{b}}$ & $3,2^{\mathrm{a}}$ & $3,2^{\mathrm{a}}$ & $4,4^{\mathrm{a}}$ \\
\hline & $\mathrm{SE}_{\mathrm{LSM}}$ & 0.11 & 0.11 & 0.04 & 0.05 & 0.02 & 0.01 & 0,12 & 0,12 & 0,04 \\
\hline \multirow{2}{*}{$\mathrm{T} 4$} & LSM & $3.8^{\mathrm{a}}$ & $3.8^{\mathrm{a}}$ & $4.9^{\mathrm{a}}$ & $2.5^{\mathrm{d}}$ & $2.6^{\mathrm{c}}$ & $2.1^{\mathrm{e}}$ & $3,1^{\mathrm{a}}$ & $3,1^{\mathrm{a}}$ & $4,5^{\mathrm{a}}$ \\
\hline & $\mathrm{SE}_{\mathrm{LSM}}$ & 0.11 & 0.11 & 0.04 & 0.05 & 0.02 & 0.01 & 0,12 & 0,12 & 0,04 \\
\hline \multirow{2}{*}{ T5 } & LSM & $3.8^{\mathrm{a}}$ & $3.8^{\mathrm{a}}$ & $4.9^{\mathrm{a}}$ & $2.5^{\mathrm{d}}$ & $2.3^{\mathrm{d}}$ & $2.5^{\mathrm{b}}$ & $3,2^{\mathrm{a}}$ & $3,2^{\mathrm{a}}$ & $4,4^{\mathrm{a}}$ \\
\hline & $\mathrm{SE}_{\mathrm{LSM}}$ & 0.11 & 0.11 & 0.04 & 0.05 & 0.02 & 0.01 & 0,12 & 0,12 & 0,04 \\
\hline \multirow{2}{*}{ T6 } & LSM & $3.8^{\mathrm{a}}$ & $3.8^{\mathrm{a}}$ & $4.9^{\mathrm{a}}$ & $2.6^{\mathrm{c}}$ & $2.1^{\mathrm{e}}$ & $1.8^{\mathrm{g}}$ & $3,2^{\mathrm{a}}$ & $3,2^{\mathrm{a}}$ & $4,5^{\mathrm{a}}$ \\
\hline & $\mathrm{SE}_{\mathrm{LSM}}$ & 0.11 & 0.11 & 0.04 & 0.05 & 0.02 & 0.01 & 0,12 & 0,12 & 0,04 \\
\hline \multirow{2}{*}{$\mathrm{T} 7$} & LSM & $3.8^{\mathrm{a}}$ & $3.8^{\mathrm{a}}$ & $4.9^{\mathrm{a}}$ & $2.8^{\mathrm{b}}$ & $2.5^{\mathrm{c}}$ & $2.4^{\mathrm{c}}$ & $3,1^{\mathrm{a}}$ & $3,1^{\mathrm{a}}$ & $4,4^{\mathrm{a}}$ \\
\hline & $\mathrm{SE}_{\mathrm{LSM}}$ & 0.11 & 0.11 & 0.04 & 0.05 & 0.02 & 0.01 & 0,12 & 0,12 & 0,04 \\
\hline \multirow{2}{*}{$\mathrm{T} 8$} & LSM & $3.8^{\mathrm{a}}$ & $3.8^{\mathrm{a}}$ & $4.9^{\mathrm{a}}$ & $2.7^{\mathrm{bc}}$ & $2.7^{b}$ & $2.3^{\mathrm{d}}$ & $3,1^{\mathrm{a}}$ & $3,1^{\mathrm{a}}$ & $4,4^{a}$ \\
\hline & $\mathrm{SE}_{\mathrm{LSM}}$ & 0.11 & 0.11 & 0.04 & 0.05 & 0.02 & 0.01 & 0,12 & 0,12 & 0,04 \\
\hline
\end{tabular}

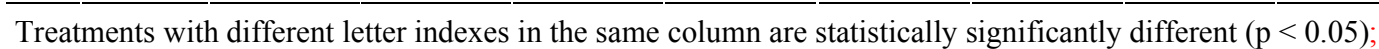

${ }^{a}$ - statistically no significant differences; ${ }^{\text {ab, bc }}$ - statistically significant diferences 


\section{CONCLUSIONS}

Based on the obtained results, it can be with certainty concluded that the addition of garlic, black pepper and hot red pepper in broiler chicken nutrition have positive effect on production performances. Addition of hot red pepper in amount of $0.5 \mathrm{~g} / 100 \mathrm{~g}$ has led to highest final body weights. Also, obtained results indicate that garlic, black pepper and hot red pepper are effective in regulation of lipid metabolism in a favourable manner. Addition of garlic, black pepper and hot red pepper had significant influence on crude fat digestibility and utilization, but the further investigation of their mode of action is still necessary.

Acknowledgements: This paper is a part of the project III 46012 which is financed by Ministry of Education, Science and Technological Development of Republic of Serbia, and project 114-451-4685/2013-03 financed by the Provincial Secretariat for Science and Technological Development of the Autonomous Province of Vojvodina. Also the realization of one part of this experiment was supported by the Perutnina Ptuj - Topiko a.d., Petefi brigade 2, 24300 Bačka Topola, Serbia.

\section{REFERENCES}

[1] Abou-Elkhair, R., Ahmed, H. A., Selim, S.: Effects of black pepper (Piper nigrum), turmeric powder (Curcuma longa) and coriander seeds (Coriandrum sativum) and their combinations as feed additives on growth performance, carcass traits, some blood parameters and humoral immune response of broiler chickens. Asian-Australas. $J$. Anim. Sci., 27 (6), 847-854 (2014).

[2] Adibmoradi, M., Navidshad, B., Saif, D. J., Royan, M.: Effect of dietary garlic meal on histological structure of small intestine in broiler chickens. J. Poult. Sci., 43, 37883 (2006).

[3] Al-Harthi, M. A.: Efficacy of vegetable diets with antibiotics and different type of spices or their mixtures on performance economic efficiency and carcass traits of broilers. J. Agricul. Sci., 27, 3531-3545 (2002).

[4] Al-Kassie, G. A. M., Al-Nasrawi, M. A. M., Ajeena, S. J.: Use of black pepper (Piper nigrum) as feed additive in broilers diet. Res. Opin. Anim. Vet. Sci., 1, 169-173 (2011).

[5] Ashayerizadeh, O., Dastar, B., Shams Shargh, M., Ashayerizadeh, A., Rahmatnejad, E., Hossaini, S. M. R.: Use of garlic (Allium sativum), black cumin seeds (Nigella sativa L.) and wild mint (Mentha longifolia) in broiler chickens diets. J. Anim. Vet. Advan., 8 (9), 1860-1863 (2009).

[6] Bajad, S., Bedi, K., Singla, A., Johri, R.: Piperine inhibits gastric emptying and gastrointestinal transit in rats and mice. Plant Med., 67, 176-179 (2001).

[7] Fadlalla, I. M. T., Mohammed, B. H., Bakhiet, A. O.: Effect of feeding garlic on the performance and immunity of broilers. Asian J. Poult. Sci., 4 (4), 182-189 (2010).

[8] Grashorn, M. A.: Use of phytobiotics in broiler nutritionan alternative to in feed antibiotics? J. Anim. Feed Sci., 19, 338-347 (2010).
[9] Hosseini, M. N.: Comparison of using different level of black pepper with probiotic on performance and serum composition on broilers chickens. J. Bas. Appl. Sci. Res., 11, 2425-2428 (2011).

[10] Issa, K. J., Abo Omar, J. M.: Effect of garlic powder on performance and lipid profile of broilers. Open J. Anim. Sci., 2, 62-68 (2012).

[11] Khalaf, A. N., Shakya, A. K., Al-Othman, A., El-Agbar, Z., Farah, H.: Antioxidant activity of some common plants. Turkish J. Biol., 32, 51-55 (2008).

[12] Kostadinović, Lj., Lević, J.: Use of phytogenic products for pig and broiler diseases. Proceedings of 15th International Feed Technology Symposium, Novi Sad, Serbia, (2012) pp. 64-74.

[13] Lewis, M. R., Rose, S. P., Mackenzie, A. M., Tucker, L. A.: Effects of dietary inclusion of plant extraction the growth performance of male broiler chickens. British Poult. Sci., 44, S43-S44 (2003).

[14] McNab, J. M.: Amino acid digestibility and availability studies with poultry. In: Farm Animal Nutrition, edited by D’ Mello J. P. F. pp. 185-203, 1994.

[15] Moorthy, M., Ravikumar, S., Viswanathan, K., Edwin, S. C.: Ginger, pepper and curry leaf powder as feed additives in broiler diet. Inter. J. Poult. Sci., 8, 779-782 (2009).

[16] Oladele, O. A., Emikpe, B. O., Bakare, H.: Effects of dietary garlic (Allium sativum Linn.) supplementation on body weight and gut morphometry of commercial broilers. Int. J. Morphol., 30 (1), 238-240 (2012).

[17] Platel, K., Srinivasan, K.: Digestive stimulant action of spices: A myth or reality? Indian J. Med. Res., 119 (5), 167-79 (2004).

[18] Puvača, N., Stanaćev, V., Beuković, M., Ljubojević, D., Kostadinović, Lj., Džinić, N.: Effect of phytogenic feed additive (Allium sativum L.) on broiler chicken nutrition on breast meat quality and tissues cholesterol content. Proceedings of $7^{\text {th }}$ International Scientific Conference, Vukovar, Croatia, 2014, pp. 75-80.

[19] Puvača, N., Stanaćev, V., Glamočić, D., Lević, J., Perić, L., Stanaćev, V., Milić, D.: Beneficial effects of phytoadditives in broiler nutrition. World's Poult. Sci. J., 69, 2734 (2013).

[20] Reen, R. K., Roesch, S. F., Kiefer, F., Wiebel, F. J., Singh, J.: Piperine impairs cytochrome P4501A1 activity by direct interaction with the enzyme and not by down regulation of CYP1A1 gene expression in the rat hepatoma 5L cell line. Biochem. Biophys. Res. Commun., 218 , 562-569 (1996).

[21] Roth, F., Kirchgessner, X.: Organic acids as feed additives for young pigs: Nutritional and gastrointestinal effects. J. Anim. Feed Sci., 8, 25-33 (1998).

[22] Simon, O.: Micro-organisms as feed additives-probiotics. Adv. Pork Produc., 39, 161-167 (2005).

[23] Sivam, G. P.: Protection against Helicobacter pylori and other bacterial infections garlic. J. Nutr., 131, 1106S1108S (2001).

[24] Srinivasan, K.: Black pepper and its pungent principlepiperine: A review of diverse physiological effects. Crit. Rev. Food Sci. Nutr., 47, 735-748 (2007).

[25] Stanaćev, V., Glamočić, D., Milošević, N., Puvača, N., Stanaćev, V., Plavša, N.: Effect of garlic (Allium sativum 
L.) in fattening chicks nutrition. Afr. J. Agri. Res., 6, $943-$ 948 (2011).

[26] Stanaćev, V., Milošević, N., Plavša, N., Bjedov, S., Stanaćev, V., Puvača, N., Arapović, Ž.: Phytoadditives (Allium sativum L.) in the diet of fattening chickens. Proceedings of the $14^{\text {th }}$ International Symposium of Feed Technology, Novi Sad, 2010, pp. 295-302.

[27] Tazi, S. M. E., Mukhtar, M. A., Mohamed, K., Tabidi, M. H.: Effect of using black pepper as natural feed additive on performance and carcass quality of broiler chicks. Int. J. Pharm. Res. Analy., 4, 108-113 (2014).

[28] Tollba, A. A. H., Hassan, M. S. H.: Using some natural additives to improve physiological and productive performance of broiler chicks under high temperature conditions 2 - black cumin (Nigella sativa) or garlic (Allium sativum). Egypt. Poult. Sci., 23, 327-340 (2003).

[29] Valiollahi, M. R., Rahimian, Y., Miri, Y., Rafiee, A.: Effect use ginger (Zingiber officinale), black pepper
(Piper nigrum L.) powders on performance, some blood parameters and antibody titter against new castle vaccine on broiler chicks. Sch. J. Agri. Sci., 3 (12), 535-540 (2013).

[30] Wierup, M.: The Swedish experience of the 1986 ban of antimicrobial growth promoters, with special reference to animal health, disease prevention, productivity, and usage of antimicrobials. Mic. Drug Res., 7, 183-190 (2001).

[31] Windish, W., Schedle, K., Plitzner, C., Kroismayr, A.: Use of phytogenic products as feed additives for swine and poultry. J. Anim. Sci., 86, 140-148 (2008).

[32] Zekić, V., Puvača, N., Milić, D., Beuković, M., Glamočić, M., Vukelić, N., Lukač, D., Zekić, S.: Effect of garlic powder in broiler chicken nutrition: Emphasis on production economic efficiency coasts and chicken meat quality. Custos e @gronegócio on line., 10 (2), 86-98, Abr/Jun (2014). 